\title{
Versiones latinas de la historia del tesoro maldito
}

\author{
Marcos Ruiz SÁNCHEZ \\ Universidad de Murcia \\ marcosr@um.es
}

Recibido: 3 de marzo de 2014

Aceptado: 5 de septiembre de 2014

\section{RESUMEN}

El presente trabajo estudia varios ejemplos del tipo AT 763, prestando especial atención a las versiones latinas. Se analiza el papel de los personajes, así como la repercusión que para la evolución de la historia ha tenido el cambio desde las formas tradicionales del relato a la ficción moderna.

Palabras clave: Exempla medievales. Chaucer. Cuento del vendedor de indulgencias. Novella. Morlini. Cuentos populares. AT 763 (Los buscadores del tesoro que se asesinan unos a otros).

Ruiz SÁnchez, M., «Versiones latinas de la historia del tesoro maldito», Cuad. Fil. Clás. Estud. Lat. 34.2 (2014) 241-265.

\section{Latin tales based upon cursed treasure story}

\begin{abstract}
The present study examines several examples of tale type AT 763, with special attention paid to the versions in Latin. The role of the characters is analysed together with the repercussions that the change from the traditional forms to modern fiction have had on the story's evolution.
\end{abstract}

Keywords: Medieval exempla. Chaucer. Pardoner's Tale. Novella. Morlini. Folktales. AT 763 (The Treasure Finders who Murder One Another).

Ruiz SÁnchez, M., «Latin tales based upon cursed treasure story», Cuad. Fil. Clás. Estud. Lat. 34.2 (2014) 241-265.

Sumario: 1. La historia del tesoro maldito (AT 763). 2. El carácter modélico de los personajes. 3. El falso discípulo. 4. Los exempla medievales. 5. El personaje del ermitaño. 6. La lección oscura y el rastro de sangre. 7. El tentador. 8. El origen del tesoro y sus implicaciones. 9. Del relato edificante al cuento de ficción. 10. Referencias bibliográficas. 


\section{LA HISTORIA DEL TESORO MALDITO (AT 763)}

Los relatos del tipo AT 763 (The Treasure Finders who Murder one Another) constituyen uno de los cuentos moralizantes más difundidos por todo el mundo, del que existen multitud de versiones populares y literarias (Aarne - Thompson 1973) ${ }^{1}$. Entre estas últimas hay varias versiones latinas. La más extensa es la de Girolamo Morlini (1983, pp.202-205), novelista italiano que vivió en Nápoles entre los siglos XV y XVI (novela XLII, De illis, qui in Tiberi reperto thesauro, adinuicem conspirantes, ueneno et ferro periere):

De illis qui, in Tiberi reperto thesauro, adinuicem conspirantes, ueneno et ferro periere.

Magus magico susurro in Tiberi delitum thesaurum quadam in cauea spirituum reuelatione cognouit. Quo reperto, cum magnum siclorum cumulum aspiceret, < ........................... >. Comuni uoto pars sotiorum proximum oppidum seu castellum epulas aliasque res comparaturi accedunt, ceteri uero copiosum interea ignem instruunt, thesaurumque custodiunt. Dumque in castellum conuenissent, radice malorum cupiditate affecti, ut consotios thesauri parte priuarent, diro ueneno illos interimere statuerunt. Cum dicto, in caupona epulantes, ebrii ac uino sepulti aliquatenus moram fecere.

In Tiberi expectantes atque exurientes consotios de mora incusabant, Iouemque adiurauerunt repedantes ex oppido atque castello et uita et thesauri parte priuare. Sicque adinuicem conspirantes, non multo post adueniunt ex pago illi uinarios utres, pullos, pisces aliaque dulcis saporis pulmentaria atque praelectum hircum ferentes, quibus ouiam dederunt ieiuni illosque omnes morti imparatos incautosque insecauere atque crudeli strage perdiderunt. Pone, sumptis cibariis diro ueneno tabefactis, insigni facilitate gnauiter cuncta ministrare incipiunt: alter uerrit, alter sternit, pars coquit atque tucenta concinnat; pone omnibus scitule appositis ac mensa largiter instructa, edere ceperunt, omniaque ingurgitauerunt. Commodum $<\ldots \ldots . . .>$ ex eis mensa erecti erant quod, morte preuenti, cum sociis uitam fato reddentes, sub elemento mortui et sepulti remansere.

Nouella indicat nec esse de malo cogitandum: nam quod quis seminat, metit.

Podemos traducirla del siguiente modo 2 :

«Sobre los que habiendo encontrado un tesoro en el Tíber, conspirando unos contra otros murieron por el veneno y la espada.

Un mago por un misterioso encantamiento supo, gracias a una revelación de los espíritus, que un tesoro había sido escondido en el Tíber en cierta fosa. Encontrado éste, viendo un gran cúmulo de siclos....... De común acuerdo, una parte de los socios se acerca a una ciudad próxima o castillo para comprar alimentos y otras cosas; los de-

\footnotetext{
${ }^{1}$ El índice de motivos lo cataloga como K1685 (Thompson [1955-19582]). La mayor parte de la bibliografia sobre el relato se centra en la versión de Chaucer. Cf. para la historia del tipo los estudios de Clouston (1887, pp.379-412), Canby (1905, pp.477-448), Fradejas Lebrero (1987) y Pedrosa (2000). Un intento de tipología de las distintas versiones puede verse en el artículo de Hamel y Merrill (1991).

2 De no indicarse explícitamente lo contrario, la traducción de los textos latinos es siempre mía.
} 
más disponen entretanto un gran fuego y custodian el tesoro. Y tras llegar los unos a la ciudad, movidos por el deseo, raíz de todos los males, de privar a los cómplices de una parte del tesoro, decidieron matarlos con un terrible veneno. Tras llegar a este acuerdo, se retrasaron un tanto comiendo en una posada, ebrios y sepultados por el vino.

Los que aguardaban en el Tíber y estaban hambrientos, acusaban a sus cómplices de la tardanza y juraron a Dios que los privarían de la vida y de su parte del tesoro al regresar de la ciudad y del castillo. Y así conspirando recíprocamente, no mucho después regresan aquellos de la aldea llevando odres de vino, pollos, peces y otras viandas de dulce sabor y un cabrito escogido. A su encuentro salieron los que estaban en ayunas y sin que estuvieran preparados para la muerte y, sin que nada temieran, los degollaron y aniquilaron en cruel carnicería. Después, tras coger los alimentos impregnados del horrible veneno, comienzan a servir todas las mesas diligentemente: uno barre, otro nivela el suelo; otro grupo cuece y prepara la pastelería; después, servidas las cosas con gracia y preparada la mesa copiosamente, comenzaron a comer y engulleron todo.... Después de esto, tras levantarse de la mesa, cogidos de improviso por la muerte, perdiendo su vida como sus compañeros, quedaron muertos y sepultados al aire libre.

La novela muestra que no deben hacerse planes malvados: pues lo que se siembra se recoge».

El cuento de Morlini es bastante singular dentro de la historia del tipo. Presenta, en efecto, notables diferencias con las versiones medievales del relato que lo han precedido y con las que suele ser relacionado.

Además del texto del autor napolitano, pueden citarse otros ejemplos latinos de la historia del tesoro: varios exempla medievales y un cuento incluido entre los epigramas de Giambattista Bargiocchi. A ellos hay que añadir desde el siglo XVII las traducciones en latín de las leyendas orientales. En el presente trabajo trataremos de situar dichas versiones con respecto a las variantes a que da lugar el tipo AT 763 .

\section{EL CARÁCTER MODÉLICO DE LOS PERSONAJES}

A pesar de lo que podría parecer, los casos en que el cuento se limita al escueto relato de los hechos son raros en la literatura oral. Un ejemplo es el siguiente, procedente del norte de África (Basset 1887, p.107):

Trois individus étaient allés couper les routes: ils arrêterent un homme, le tuèrent et prirent son argent. Ils envoyèrent l'un d'eux chercher des mets délicats et convinrent entre eux de le tuer. L'autre se dit en partant: «Je mettrai du poison dans la marmite». Quand il revient, ils l'assasinèrent. Il mourut le premier, les deux autres périrent et le trésor resta sans maître.

El número de los protagonistas de la historia central varía mucho y lo mismo ocurre con su condición, pudiendo ser ladrones, comerciantes o simples viajeros.

En muchos de los cuentos frente a los personajes que intervienen directamente en la acción hay otros que actúan como meros espectadores. Aparecen al final del 
relato y a veces también al comienzo. Este tipo de personajes actúan como centros de planteamientos ideológicos diferentes. Esta función exige naturalmente dos papeles, que corresponden a las figuras arquetípicas de un maestro y su discípulo. El discípulo representa -habitualmente, pero no necesariamente- la postura convencional ante la realidad, la visión secular del mundo, frente al maestro, que representa la auténtica sabiduría y que ve más allá de las apariencias. Por otra parte, estos dos papeles corresponden claramente a las posiciones del narrador y del lector. El maestro es el encargado de formular el «tema» del relato y la «moraleja» final. Dirá, por ejemplo, que el oro es el mundo, o que causa toda clase de maldades.

En otras ocasiones los personajes cumplen una doble función, pues comentan ideológicamente los acontecimientos al tiempo que participan en los hechos.

En los relatos en que aparecen personajes exclusivamente ideológicos el marco narrativo se crea simplemente mediante la conjunción y disyunción espacial de tales personajes con respecto a la historia. A veces, por ejemplo, Cristo pasa por el lugar de los hechos antes o después de que estos ocurran. Es él quien de forma estrictamente mostrativa señala la significación de los hechos a los discípulos. La versión más extendida de este tipo es la que aparece en los apócrifos sobre Jesús, traducida al latín por Levin Warner $(1644$, p.31) y difundida posteriormente por Fabricius $\left(1719\right.$, p.395) ${ }^{3}$ :

Tempore Iesu tres aliquando iter faciebant, qui, thesaurum inuenientes, «Esurimus», inquiunt, «ideoque unus ex nobis abibit, et cibum coemet». Vnus ille qui ibat allatum cibum, «Consultum», inquit, «erit, ut cibum ueneno inficiam, quo uescentes moriantur, egoque solus thesauro potiar». Quod fecit, et cibo uenenum admiscuit. Sed et duo illi uiri inter se conuenerant ut, cum cibum apportaret, eum interficerent, quo soli thesauro fruerentur. Cum igitur cibum ueneno mixtum afferret, eum occiderunt. Et ipsi, cibum illum uenenatum comedentes, statim sunt mortui. Cum ecce Iesus transiens cum apostolis suis dicebat. «Haec est conditio mundi! Videte quomodo ternos hosce tractauerit, et ipse tamen post eos in statu suo perseueret! Vae illi qui petit mundum ex mundo».

\footnotetext{
${ }^{3}$ Ésta es una de las versiones más difundidas de la historia del tesoro, bien a través de traducciones, bien por su influencia sobre la literatura oral. Una traducción inglesa junto al texto latino de Fabricius puede leerse en Jones (1798, pp.470-471). Galland (1694, pp.225-226) ha traducido la historia al francés:

Du temps d'Isa, trois voyageurs trouvèrent un trésor en leur chemin, \& dirent: «Nous avons faim, qu'un de nous aille acheter de quoi manger». Un d'eux se détacha, \& alla dans l'intention de leur apporter de quoi faire un repas. Mais il dit en lui-même: II faut que j'empoisonne la viande, afin qu'ils meurent en la mangeant, \& que je jouisse du trésor moi seul. Il exécuta son dessein, \& mit du poison dans ce qu'il apporta pour manger. Mais les deux autres, qui avoient conçu le même dessein contre lui pendant son absence, l'assassinerent à son retour, \& demeurèrent les maîtres du trésor. Après avoir tué, ils mangèrent de la viande empoisonnée, \& moururent aussi tous deux. Isa passa par cet endroit-là avec ses Apôtres, \& dit: «Voilà quel est le monde. Voyez de quelle manière il a traité ces trois personnes. Malheur à celui qui lui demande des richesses».

El mismo texto está traducido al inglés en Pick (1908, p.102). El texto de Galland fue recogido, casi textualmente, en recopilaciones de relatos breves, con el cambio de Jesús por un anónimo «filósofo» (Meidinger 1792, p.39).
} 
Otra versión latina, más moderna, puede leerse en Asín Palacios (1919, p.387).

Esta conformación tan simple de la leyenda parece haber sido importante para la difusión de la historia. Una serie de rasgos que caracterizan esta versión se encuentran en muchos otros ejemplos, aunque no necesariamente provengan de ella: no hay ninguna elipsis narrativa y se exponen primero las reflexiones del viajero que va a buscar comida y luego las de los otros dos; los pensamientos de los personajes contrastan con la conclusión final, que subraya que el tesoro no pertenece a nadie.

Podemos ver estos mismos rasgos, por ejemplo, en el relato citado anteriormente de R. Basset o en otros cuentos populares del norte de África, a pesar de que en ellos no aparezca el personaje encargado de comentar lo sucedido ${ }^{4}$.

Similares son también las versiones fabulísticas que pusieron de moda este relato en el siglo XVIII, procedentes de adaptaciones de las leyendas orientales. He aquí, por ejemplo, la versión que aparece en las Fables orientales de Jean-François de Saint-Lambert (1796, pp.346-347) :

Le crime

Trois habitants de Balck voyageoient ensemble: ils rencontrerent un trésor, et ils le partagerent: ils continuerent leur route en s'entretenant de l'usage qu'ils feroient de leurs richesses. Les vivres qu'ils avoient portés étoient consommés; ils convinrent qu'un deux iroit en acheter à la ville, et que le plus jeune se chargeroit de cette commission. Il partit.

Il se disoit en chemin: me voilà riche; mais je le serois bien davantage si j'avois été seul quand le trésor s'est présenté... Ces deux hommes $m$ 'ont enlevé mes richesses... Ne pourrois-je pas les reprendre?... Cela me seroit facile. Je n'aurois qu'à empoisonner les vivres que je vais acheter; à mon retour je dirois que j'ai dîné à la ville; mes compagnons mangeroient sans défiance, et ils mourroient. Je n'ai que le tiers du trésor, et j'aurois le tout.

Cependant les deux autres voyageurs se disoient: Nous avions bien affaire que ce jeune homme vînt s'associer à nous; nous avons été obligés de partager le trésor avec lui; sa part auroit augmenté les nôtres, et nous serions véritablement riches... Il va revenir, nous avons de bons poignards.

Le jeune homme revint avec des vivres empoisonnés; ses compagnons l'assassinerent. Ils mangerent; ils moururent; et le trésor n'appartint à personne.

\footnotetext{
${ }^{4}$ Cf. Guiraudon (1894, pp.82-83) y Gil Grimau - Ibn Azzuz (1988, pp.142-143). En otra versión africana (Basset 1883, pp.185-186), la historia es prácticamente idéntica a la de la leyenda, pero al final el encargado de comentar la historia es un padre que, dirigiéndose a su hijo reflexiona sobre la codicia.

${ }^{5}$ La misma fábula se encuentra en Diderot $(1798$, p.244). Al igual que tantas otras fábulas, ésta fue versificada por diferentes autores. Cf. Le trésor, Apologue par M. De Fallet (Mayeur de St. Paul 1786, pp.249$250)$. N.F. de Neufchâteau (1815, p.72) se inspira también en la leyenda apócrifa y en Diderot para ofrecer su versión. Antoine Bret (1772, pp.9-11) versifica la versión de Saint-Lambert en un largo poema que concluye: Voilà donc le trésor sans maître: / A quel humain va-t-il être remis? / Hélas! il le rendra peut-être / plus méchant que nos trois amis.
} 
La funcionalidad de los personajes que comentan la acción no hay que buscarla en relación con la acción misma, sino con la interpretación de los acontecimientos. Sirven de modelo para la construcción del sentido que ha de realizar el lector. Dichos personajes permiten ofrecer interpretaciones diferentes de la situación; formulan «lecturas» que corresponden a la que debe hacer el lector. Son, por así decirlo, centros ideológicos.

De este modo, en los cuentos que nos ocupan encontramos personajes cuya función parece ser simplemente la de «formular» intradiegéticamente el «tema» del relato, orientando la interpretación del texto y creando así una tensión narrativa, una «lógica de los posibles narrativos», paralela a la tensión determinada por el suspense en torno al resultado de las distintas acciones. Actúan, pues, como dobles del lector, encarnaciones del fantasma de éste en el texto.

Por otra parte, el sentido moralizante o tropológico de la historia implica que los personajes que participan plenamente en la acción constituyan modelos o antimodelos de conducta para los discípulos del relato en primer lugar y, en definitiva, para el lector.

Finalmente, este tipo de personajes puede desempeñar otra función, la de explicar cómo se ha podido conocer finalmente la trama de esta historia si todos sus protagonistas han muerto; justifican de este modo el propio relato, pues ¿quién podría haber contado la historia si todos los protagonistas mueren finalmente? Se hace necesaria la presencia de un «testigo» que conozca los hechos, bien por haberlos presenciado, bien por una capacidad sobrenatural que le permita reconstruirlos, bien como intérprete de los indicios que la muerte deja a su paso.

En algunos de los cuentos más antiguos el personaje que encarna al maestro espiritual reconoce lo sucedido mediante sus poderes sobrenaturales, o porque su conocimiento especial del ser humano así se lo permite.

En otra de las versiones de la leyenda de Cristo y el tesoro editadas por Asín Palacios, Cristo, que pasa con un grupo de los apóstoles junto al tesoro dice (en la traducción latina de Asín): Hoc quidem maxime lethale est; cauete ergo eum. Tras la muerte de los viajeros que encuentran el oro, regresa Jesucristo con sus discípulos, que interrogan a Cristo por lo ocurrido:

Rediens autem Iesus (quem Deus salutet!) a sua peregrinatione, illos [tres socios] iacentes uidit circum auri [thesaurum], aurum uero [integrum] ut erat antea. Cum ergo super hoc mirarentur eius discipuli eique interrogarent: «Quidnam hisce [hominibus] accidit? », hanc eis historiam narrauit ${ }^{6}$.

De modo similar en una versión de las Mil y una noches Jesús encuentra los cuerpos y suplica a Dios que le informe sobre el suceso. Luego se lo cuenta a sus

\footnotetext{
${ }^{6}$ «Al regresar Jesús - a quien Dios conceda la salvación- de su viaje, vio a aquellos tres compañeros que yacían alrededor del tesoro y el oro que estaba sin tocar como antes. Admirándose de esto sus discípulos y preguntándole qué le había ocurrido a estos hombres, les contó esta historia».
} 
discípulos (Burton 1897, pp.164-165)7. En otras ocasiones el personaje encargado de extraer la moraleja final va siguiendo el rastro de sangre, averiguando de este modo lo que ha ocurrido.

\section{EL FALSO DISCÍPULO}

Junto a las versiones en que los personajes que analizan la historia difieren totalmente de los protagonistas de los crímenes, existen otras en que al menos uno de los personajes desempeña ambas funciones. Esto da lugar a diferentes tipos. Una variante de esta clase se produce cuando alguno de los discípulos no acepta la enseñanza del maestro y se convierte posteriormente en víctima ${ }^{8}$.

Una versión de este tipo, que muchos estudiosos consideran como el origen último de nuestra historia, se encuentra en los cuentos jataka (cuentos en los que se narran historias en que intervienen las encarnaciones anteriores de Buda) (Cowell 1973, pp.121-123). Un brahmán conoce una fórmula mágica que, pronunciada en cierta conjunción astral, hace que caigan joyas del cielo. El brahmán está tomando lecciones de un bodhisatta (una de las encarnaciones de Buda). Ambos son asaltados por una banda de quinientos ladrones. Los bandidos retienen al más rico y envían al otro a la ciudad para que les traiga el rescate. Antes de partir el bodhisatta advierte al brahmán que no pronuncie su fórmula mágica. Pero por la noche el brahmán no puede contener su impaciencia y recita la fórmula haciendo que lluevan las joyas. Espera que con eso los ladrones lo pongan en libertad. En ese momento una segunda banda de quinientos ladrones vence a la primera. Los ladrones delatan al brahmán, pero éste no puede hacer llover de nuevo joyas del cielo hasta que pase otro año. Los bandidos lo matan y disputan por la posesión de las joyas. Al final quedan vivos tan

\footnotetext{
${ }^{7}$ En un cuento hindú (Gallud Jardiel 2000, pp.93-95) cuatro mercaderes, a los que guía el afán de lucro, cruzan un denso bosque, cuando observan que algo brilla junto al tronco de un árbol. Se trata de un lingote de oro. Dos de ellos regresan al pueblo, con la intención de comprar algunos manjares, mientras los otros les aguardan. Sigue la historia de los asesinatos. A la mañana siguiente un asceta encuentra los cuatro cadáveres. Coge el lingote de oro y lo arroja a las aguas.

${ }^{8}$ En la colección de los Avadânas (Julien 1859, I, pp.60-63) hay una historia similar, pero en la que falta el motivo esencial de los asesinatos cruzados. Buda y su discípulo Ananda viajan a través de un paraje desierto y ven un montón de oro depositado al borde de un campo. Buda dice a Ananda: «Es una gran serpiente venenosa». «Es verdad, es una maligna serpiente» responde Ananda. Un trabajador, que ha oído lo que han dicho, picado por la curiosidad, descubre el oro y lo lleva a su casa. Convertido en rico y opulento, el hombre empieza a realizar gastos excesivos. Los espías del rey, asombrados de su fortuna repentina, lo llevan a la cárcel; grita: «En verdad era una serpiente venenosa». Quienes lo escuchan, informan al rey, que pide al hombre que explique el significado de sus palabras. Otra versión de la misma historia puede verse en el tomo II de la misma obra (Julien 1859, II, pp.89-91). El relato comienza de forma similar, aunque el final es algo diferente. En estos cuentos el tesoro es descubierto y rechazado también por un maestro espiritual y la afirmación de que se trata de una serpiente, recuerda claramente la de que el tesoro es la muerte, frecuente en algunas versiones de los cuentos que nos ocupan; en este caso hay, sin embargo, un marcado contraste entre el auténtico discípulo y el receptor ocasional, cosa que en realidad prefigura dos tipos de enseñanza y de receptor; el segundo, que representa la sociedad en general, sólo aprenderá a través de la experiencia.
} 
sólo dos bandidos. El que había quedado guardando las joyas mata a su compañero y muere luego al comer el arroz que el otro había envenenado. El cuento concluye con el regreso y la reflexión final del bodhisatta, que va descubriendo uno por uno los cadáveres y reconstruyendo la historia ${ }^{9}$.

El tema del discípulo descarriado es característico de toda una serie de versiones orientales de la historia del tesoro maldito. En el área cultural musulmana encontramos una serie de cuentos complejos, en los que el discípulo fallido es quien primero entra en posesión del tesoro, para inmediatamente ser asesinado por los ladrones. Cristo viaja con un acompañante; comparten tres panes, pero el compañero se come uno. Jesús hace varios milagros (resucita una gacela, camina sobre las aguas de un río, etc.). Tras cada uno de ellos pregunta de nuevo a su compañero por el pan en cuestión. El otro sigue negando. Finalmente es la codicia la que lo hace confesar. Encuentran tres lingotes de oro (o estos son producto de otro milagro). Jesús hace tres montones: el tercero será para quien se comió el tercer pan. Es sólo entonces cuando se produce la confesión y Jesús abandona a su compañero dejándole los lingotes. Sigue la historia normal de los asesinatos. Cuando pasa por allí de nuevo Jesús pronuncia la moraleja de la historia: «Esto hace el mundo con las gentes que a él se entregan $\rangle^{10}$.

Dos de estas versiones - junto a otras dos de diferente tipo- se encuentran en dos leyendas sobre Cristo editadas por Asín Palacios. La más parecida a las otras versiones de este tipo del área cultural musulmana es la segunda (Asín Palacios 1919, pp.385-386). En ella tras los milagros realizados por Cristo el tesoro es encontrado en una ciudad en ruinas:

Exeuntes itaque [ex ualle illa discesserunt] usque dum peruenerunt in quamdam uillam magnam, omnino uastatam, et ecce prope illam tres aureos lateres [inuenerunt]. [Quos cum uidisset] homo ille dixit: «Ecce thesaurus! " [Iesus] autem (quem Deus salutet!) dixit: "Thesaurum hocce [sic] dispertiar: laterem unum mihi, alterum tibi, alterum uero homini illi panis [furatori]». Respondit ille: «Ego [sum] ille panis [furator]». Dixit [Iesus] (quem Deus salutet!): «Tres omnes [lateres] tibi sint». Et [haec dicens] ab eo discessit.

«Salieron de aquel valle y llegaron a una gran ciudad, totalmente en ruinas, $y$ he aquí que encontraron tres lingotes de oro. Al verlos, el hombre dijo: «iEs un tesoro!» Jesús -sobre él sea la salvación- dijo a su vez: «Dividiré el tesoro del siguiente modo: un lingote para mí, otro para ti y otro para el que robó el tercer pan.» «Yo soy el que robó el pan», dijo su compañero. «Sean para ti todos los lingotes», dijo Jesús -sobre él sea la salvación-y diciendo esto se separó de él».

\footnotetext{
${ }^{9}$ El enfrentamiento entre bandas enteras de ladrones se da también en otra versión oriental de esta historia. Cf. «The Punishment of Avarice» (Schiefner 1988, pp.286-287).

${ }^{10}$ Cf. «Jésus et les pains» (Basset 1927, pp.80-183) y «Jesus et la galette de pain», en Le libre des ruses (Khawam 1976, pp.160-163). Un largo relato de este tipo puede leerse en Siddi Lebbe (1884). Cf. Guillén Robles (1994, pp.53-57).
} 
El hombre permanece junto al tesoro, sin poder llevárselo por faltarle un medio de transporte. Tres hombres que pasan por allí le dan muerte. Tras la posterior historia de los asesinatos pasa de nuevo Jesús, que pronuncia la moraleja final: ita mundus cum suis se gerit! («Así es como el mundo trata a los suyos»).

La otra versión (Asín Palacios 1919, p.384-385) difiere de ésta tan sólo en algunos detalles. Por ejemplo, el oro es fabricado por el propio Jesús a partir de un montón de polvo y arena y el discípulo fallido se convierte en uno de los tres protagonistas de los crímenes, mientras que en otras versiones es asesinado por los ladrones. También en este caso la historia acaba con una sentencia similar: Hic est mundus! Eum ergo cauete! $!^{11}$

Evidentemente en estas versiones la pareja Cristo - falso discípulo corresponde a la que aparecía en el relato jataka. La historia del mentiroso existe, por otra parte, de forma independiente en los cuentos populares occidentales, bien por sí misma, bien integrada en cuentos más complejos ${ }^{12}$. Es posible, pues, una contaminación entre una leyenda sagrada de este tipo y la historia oriental del tesoro maldito ${ }^{13}$.

11 En un cuento popular marroquí, «Cuento de nuestro señor Jesús» (González Palencia 1946, pp.331-371) un hombre encuentra en un cementerio tres montones de dinero. Otros dos lo ven y le piden que reparta el dinero con ellos. Como teme que lo maten, acepta. Encargado de traer provisiones de la ciudad, envenena el pan. Al volver, los otros lo matan y mueren a continuación al tomar la comida. Jesús pasa por el cementerio y encuentra a los muertos junto a tres montones de dinero. Los resucita, parte entre ellos el dinero y los envía a un convento, donde se hacen cristianos. Evidentemente se trata de una versión intermedia. También aquí el primero que encuentra el tesoro se convierte en uno de los protagonistas de los asesinatos. Pero falta precisamente el episodio de Jesús y el mentiroso, que es, sin duda, un elemento procedente de la fusión de la historia con otro tipo de leyendas. Jesús aparece sólo al final. La moralidad que pronuncia es idéntica a la que se utilizaba en las leyendas citadas: «Este dinero es el mundo, y el mundo es semejante a un perro, y a los que lo siguen sin regla he aquí lo que les sucede». La resurrección final de los protagonistas corresponde a la asociación, propia del mundo musulmán, entre Jesús y la resurrección.

${ }^{12}$ Esta historia suele aparecer integrada en un ciclo de cuentos populares con muchas variantes: AT 330 (The Smith Outwits the Debil), que presenta a su vez numerosas variaciones, y AT 753 (Christ and the Smith). En España estos cuentos suelen estar asociados al personaje de Juan Soldado, que, a diferencia del compañero mentiroso de Jesús, primero ayuda a Cristo y a S. Pedro, por lo que finalmente será recompensado, a pesar de sus posteriores mentiras.

${ }^{13}$ Según Fradejas (1987), la tradición del cuento jataka se habría escindido en dos ramas, una occidental y otra oriental. Esta última se caracterizaría por la contaminación entre el cuento del tesoro y el motivo del cor cervi de las fábulas grecolatinas, en las que un animal astuto niega haber comido el corazón del ciervo, porque el animal «no tenía corazón». De dicha rama oriental dependerían los cuentos españoles que desarrollan el motivo del mentiroso, aunque estos últimos no presenten nunca la historia de los ladrones y el tesoro. Esta hipótesis es poco verosímil. Entre la versión oriental del discípulo fallido y los exempla medievales existen evidentes relaciones. Canby (1905) y otros autores ven precisamente en la leyenda de Cristo y el mentiroso el estadio intermedio entre el cuento budista y los exempla occidentales. Por otra parte, la historia del mentiroso existe independientemente de la del tesoro maldito en cuentos en que S. Pedro hace el papel del mentiroso y la narración acaba simplemente con el reconocimiento de la mentira. Además, tanto aquellos cuentos en que la historia del mentiroso aparece independientemente como aquellos en que se integra en un relato más complejo, están presentes por toda Europa. En el ciclo de Juan Soldado el tema de las mentiras es secundario y puede no aparecer. El núcleo de la historia presenta en este caso notables puntos de contacto con los cuentos de «Juan sin miedo» (AT 326: The Youth Who Wanted to Learn What Fear Is) y con el mito de Sísifo; las divinidades de incógnito entre los hombres y la resurrección son también motivos míticos comunes. Este tipo de personaje de los cuentos folclóricos tiene probablemente su origen en historias sobre un héroe cultural, mediador entre el mundo de los hombres y el de los muertos. En los cuentos populares se enfrenta unas veces al diablo y otras 


\section{LOS EXEMPLA MEDIEVALES}

Una variante de este tipo de versiones la encontramos también en los exempla medievales en los que son dos los discípulos descarriados y son ellos mismos quienes se convierten en protagonistas de los asesinatos (Correale - Hamel 2003, p.289):

De Contemptu Mundi

Cum quidam philosophus ambularet per quodam nemus cum discipulis suis, inuenerunt maximam quantitatem auri. Et quesierunt discipuli ab eo, «Quid hoc est?» Respondit, «Filii, mala res est. Nolite tangere, nam propter illud fiunt homicidia, furta, periuria». Et hiis dictis abierunt. Duo autem ex ipsis temptati dixerunt ad inuicem. «Vnus eat ad emendum panem et alius ad educendum mulum». Ille uero qui panem emerat cogitauit qualiter socium interficeret, ut totum aurum haberet. Et acceptis duobus panibus, unum toxicauit ut daret socio. Similiter alter cogitauit qualiter socium occideret. Et cum uenissent ad nemus, dixit ille qui panem portauerat, «Comedamus»; alius dixit, «Expecta me et comede, et ego incidam baculum ad educendum mulum». Et iuit et, facto baculo, latenter interfecit socium. Et cogitans habere aurum totum, cepit comedere panem toxicatum. Et sic mortuus est et ipse.

«Yendo un filósofo caminando por un bosque con sus discípulos, encontraron una cantidad muy grande de oro. Y los discípulos le preguntaron, «¿Qué es esto?» Él respondió: «Hijos, es una cosa mala. ¡No lo toquéis, pues por su culpa se producen homicidios, hurtos y perjurios». Y, habiendo dicho esto, se marchó. Pero dos de ellos, tentados, se dijeron el uno al otro: «Que uno vaya a comprar un pan, y el otro en busca de un mulo». Pero el que compró el pan reflexionó sobre cómo podría matar a su compañero para quedarse él con todo el oro. Y después de comprar dos panes, envenenó uno para dárselo a su compañero. Y al llegar al bosque, el que había traído el pan, dijo: «¡Comamos!», y el otro dijo: «Espérame y come, que voy a cortar un bastón para guiar la mula.» Y fue y, habiendo cortado el bastón, mató a traición a su compañero. Y pensando tener todo el oro, comenzó a comer el pan envenenado. Y así murió también él mismo».

Otra versión similar es la siguiente (Correale - Hamel 2003, pp.289-291):

Legitur in legenda beati Bartolamei quod, cum dominus noster Yhesus Christus ambularet cum discipulis suis per quoddam nemus et uastam solitudinem, inuenerunt

\footnotetext{
a la muerte, lo que constituye una polarización de una misma materia en dos direcciones diferentes. Hay, por otra parte, una evidente diferencia entre el tratamiento del tema del cor cervi en ambos cuentos. En la fábula la negación se refiere a haber comido el corazón del ciervo; en el cuento oriental el mentiroso niega haber comido el pan y la resurrección del ciervo constituye una forma de coacción contra él; Juan Soldado niega haber comido el corazón de un cordero y después intenta imitar a Cristo tratando en vano de resucitar a un muerto. En los cuentos orientales el intento de imitación fallido aparece en la historia de Cristo y el judío conservada por M.C. Siddi Lebbe (1884). Todo apunta, pues, a que la contaminación entre el motivo del cor cervi y los cuentos del tesoro no se ha producido directamente, sino a través de un cuento similar a los actuales sobre S. Pedro como mentiroso. La historia del discípulo mentiroso sería, pues, el fruto de la fusión de dos relatos independientes. Los cuentos del tipo «Juan Soldado» y «Juan sin miedo» son obviamente independientes del tesoro y no un desarrollo de éste. El motivo del descuartizamiento en el caldero y la resurrección no puede extrañarnos en relación con este tipo de personaje, en cuya génesis el enfrentamiento con la muerte era un rasgo esencial.
} 
unum saccum auro et argento plenum. Eo inuento dixerunt discipuli ad Yhesum, «Quid est hoc, magister?». Qui respondit, «Filioli mei, nolite hoc tangere, quia res pessima est. Nam propter hoc sepe funt homicidia, periuria, furta, alia quoque infinita mala et peccata; et propter hoc multe anime descendunt ad abissum inferni». Dixerunt discipuli tamen, «Dicas quid est hoc. Quod nomen habet?». Dixit ei $[s]$ dominus, «Aurum est et aurum uocatur. Cauere tamen debetis ne illud tangatis». Hoc dicto abire ceperunt. Duo autem ex discipulis temptati ad inuicem dicunt, "Eamus et accipiamus aurum et possidemus illud; et sic semper diuites et pleni erimus». Qui cum dixerunt ad inuicem ut unus eorum iret ad emendum cibaria neccessaria; alius iret ad aquirendum unum mullum qui asportaret auri et argenti saccum. Quod et factum est, sed uterque, iam sagita diaboli per inuidiam uel auaritiam percusus, cogitauit qualiter alium posset interficere. Ille uero qui panem emerat in uno pane posuit tosicum ut socium cecideret comendendo panem. Alius uero dixit socio, postquam ambo ad saccum peruenerunt, «Expecta me hic, donec uadam et incidam unum baculum ad deducendum mullum», cogitans et intendens alium suo baculo interficere. Qui, facto baculo, reuersus ad socium inuenit eum panem non tosicatum comedentem; qui abrecto baculo latenter occidit eum, dicens intra se, «Modo solus totum aurum possidebo». Et accurens ad panem ut comederet occurrit ei panis in quo tosicum erat; quo gustato et statim cecidit mortuus. Vnde sic patuit quod dominus uerum dixit quando dixit, «Filioli mei, nolite hoc tangere, quia res pessima est». Volens autem dominus postmodum noster Yhesus Christus hostendere huius rei ueritatem discipulis suis, uenit cum eis ad locum predictum et dixit eis, «Sic dixi uobis: quod propter aurum et argentum multa mala fiunt, sic ut uidetis; modo accidit hic». Quo uiso abierunt.

«Se lee en la vida de San Bartolomé que, cuando nuestro Señor Jesucristo caminaba con sus discípulos a través de un bosque y de las vacías soledades, encontraron un saco lleno de oro y plata. Al encontrarlo, dijeron los discípulos a Jesús: «¿Qué es esto, Señor?» Él respondió: «Hijos míos, no lo toquéis, porque es la peor de las cosas, pues a causa de esto se realizan a menudo homicidios, perjurios, robos, y otros infinitos males y pecados y debido a esto descienden muchas almas al abismo del infierno.» Los discípulos le dijeron, sin embargo, «Dinos lo que es. ¿Cuál es su nombre?» El Señor les dijo: «Es oro, y se llama oro. Pero debéis tener cuidado, sin embargo, de no tocarlo.» Dicho esto, empezaron a marcharse. Sin embargo, dos de los discípulos, tentados, se dicen el uno al otro: «Vayamos a buscar el oro y poseámoslo. Y así seremos siempre ricos y estaremos satisfechos.» Entonces planearon que uno fuera a comprar las necesarias provisiones y el otro a adquirir un mulo, para transportar el saco de oro y plata. Y así se hizo, pero cada uno, golpeado ya por la flecha del diablo mediante la envidia y la avaricia, meditaba cómo podría matar al otro. El que había comprado el pan puso, por su parte, veneno en un pan para matar a su compañero cuando lo comiera. El otro le dijo a su compañero, después de que ambos llegaron junto al saco, «Espérame aquí, mientras yo voy a cortar un bastón para guiar el mulo», con la intención de matar al otro con su bastón. Éste, después de haber cortado el bastón, volvió, pues, junto a su compañero y lo encontró comiendo el pan que no estaba envenenado, y levantando el bastón lo mató a traición, diciendo para sí mismo: "Ahora poseeré yo solo todo el oro.» Y yendo a comer el pan, dio con el pan envenenado, y nada más probarlo, al punto cayó muerto. Se hizo así evidente que nuestro Señor dijo la verdad cuando dijo: «Hijos míos, no toquéis esto, porque es la peor de las cosas.» Nuestro Señor Jesucris- 
to, por su parte, deseando después mostrar la verdad de esto a sus discípulos, vino con ellos hasta el lugar ya mencionado, y les dijo: «Ya os dije que por causa del oro y la plata ocurren muchos males, como veis que acaba de suceder aquí». Y, tras ver esto, se marcharon».

Este relato representa probablemente una contaminación de diferentes versiones. El que los protagonistas de los crímenes sean los discípulos corresponde a la forma de la leyenda en que aparece el discípulo descarriado. Naturalmente, falta la historia anterior del falso discípulo, pues en este caso son dos los personajes. Por otra parte, también aquí Jesús y sus discípulos aparecen al comienzo y al final y la moralidad intradiegética se da ya al comienzo del relato. Aquí se dice del oro: res pessima est. Nam propter hoc sepe fiunt homicidia, perjuria, furta, alia quoque infinita mala et peccata.

Es probable que este otro exemplum medieval en el que los protagonistas son sólo dos sea un testimonio de la influencia de este tipo de versiones, aunque carezca de personajes ideólogos (Klapper 1911, p.71):

De duobus sociis, qui thesaurum inuenerunt.

Per hanc uiam ambulauerunt hii duo, de quibus legitur: Duo socii auari ambulauerunt et quoddam pondus auri in uia inuenerunt. Quod tollere cupientes et pre grauedine non ualentes extra uiam cum difficultate mouerunt. Simul igitur condixerunt, ut unus ad ciuitatem iret pro asino et alius ad auri custodiam remaneret. Vadens igitur unus cogitauit, qualiter totum aurum posset habere et socium suum interficere. Similiter et qui remanserat eadem cogitabat. Ille igitur qui ad ciuitatem ierat, fecit fieri duos panes et miscuit uenenum, ut panem manducans socius moreretur. Veniens igitur cum asino et pane nitebatur aurum asino imponere dicens socio, quod pranderet, ut uires reciperet. Cui socius dixit, quod prius uellet eum iunare, et statim percuciens eum gladio iugulauit. Quo mortuo, cum esset famelicus, accepit unum panem, comedit et reliquum asino dedit. Qui ambo manducantes in terram mortui ceciderunt. Hec ad litteram fortassis gesta sunt in hac uia spinosa, sed moraliter adhuc semper contingunt.

«Los dos compañeros que encontraron un tesoro.

Cuentan que una vez dos amigos avaros pasaban por un camino y encontraron en medio de él una carga importante de oro. Quisieron llevárselo, pero no lo consiguieron por su peso excesivo, y únicamente a duras penas lograron apartarlo a un lado del camino. Entonces, determinaron en común que uno iría a la ciudad en busca de un asno y el otro se quedaría en aquel lugar para custodiar el oro hasta que el primero volviese. Así lo hicieron: el primero, mientras iba de camino a la ciudad pensaba cómo se las arreglaría para matar a su compañero y hacerse así dueño único del oro, e, igualmente, el que se había quedado pensaba lo mismo. El amigo que había marchado a la ciudad, al llegar allí, mandó cocer dos panes y puso veneno para que su compañero muriera al comerlo. Cuando estuvo de regreso con el pan y con el asno, cuando iba a cargar el oro dijo a su compañero que comiese para reponer fuerzas, a lo que aquél contestó que antes quería ayudarle y al hacerlo le atacó con un cuchillo y le mató. Una vez muerto, como se sentía con hambre, comió un pan y dio el otro al asno y ambos al comerlo cayeron muertos en tierra. 
Estas cosas quizá no ocurrieron al pie de la letra en este camino espinoso de nuestra vida, pero moralmente aún siguen sucediendo ${ }^{14} \gg$.

Este exemplum coincide con los anteriormente citados en que los protagonistas son dos y en que el motivo para que los compañeros se separen es no sólo la comida sino el transporte. En ambos casos uno de los ladrones compra dos panes; pone veneno en uno de ellos y se queda el otro para sí mismo.

Resulta igualmente interesante ver la relación existente entre este exemplum y la primera versión del Novellino, que atestigua una vez más la convivencia de las distintas variantes en la tradición y cómo han influido las unas en las otras ${ }^{15}$. En este caso Cristo y sus discípulos aparecen de nuevo al comienzo y al final de la historia. Caminan por un lugar desierto y ven brillar un montón de monedas; los discípulos sugieren cogerlas, pero Jesús los disuade diciéndoles: "Voi volete quelle cose che toglie al regno nostro la maggiore parte dell' anime. E che ciò sia vero, alla tornata ne vedrete l'asempro». Los asesinos son en este caso distintos de los discípulos, pero hay una serie de coincidencias con los exempla que acabamos de considerar: los viajeros son dos; se señala la amistad existente entre ambos: en un caso se habla de «dos amigos avaros», mientras el Novellino habla de «amigos entrañables»; el encargado de conseguir provisiones envenena los panes y en ambos casos uno de los panes acaba con la bestia de carga, un asno en el exemplum y una mula en el Novellino.

\section{EL PERSONAJE DEL ERMITAÑO}

En toda una serie de versiones occidentales de la historia del tesoro maldito aparece el personaje característico del eremita, que hereda en parte los papeles de Buda o Cristo y del falso discípulo. Es él quien descubre el tesoro y quien provoca que los ladrones lo encuentren ${ }^{16}$. Pero, a diferencia del falso discípulo, rechaza el tesoro. Al perder su distanciamiento con respecto a los hechos, este personaje implica, por otra parte, un rasgo nuevo, el sufrimiento de la figura positiva.

Todos los personajes en esta tradición participan en la acción y son a la vez centros ideológicos y aparecen contrapuestos hasta el extremo: el eremita, que por su propia condición no necesita nada, y los ladrones, soldados o comerciantes, profesionalmente movidos por la codicia, que en su avaricia serán incapaces de dejar de comportarse como ladrones, una vez que han obtenido la riqueza que podría subsanar sus necesidades (Klapper 1911, p.72):

Exemplum de Auaricia. Quidam heremita uolens in nemore ortum edificare ex casu fodiendo inuenit thezaurum statimque clamauit ter magna uoce: «Mors, mors,

\footnotetext{
${ }^{14}$ Esta traducción figura en Menéndez Pidal (1958, p.234).

${ }^{15}$ LXXXIII: «Come Cristo andando un giorno co' discepoli, videro molto grande tesoro» (Battaglia Ricci 1982, p.175).

${ }^{16} \mathrm{Cf}$. para la relación de esta tradición con las versiones orientales y para otros ejemplos similares Convoy (1905) y Hart (1911).
} 
mors!» Pretereuntes uero tres socii mercatores uenerunt dicentes: «Vbi est mors, quam clamasti?» ille uero monstrauit eis thezaurum et statim eum abinde repulerunt. Qui recedens uenit ad cellam suam. Isti uero cogitantes, quid essent facturi, ordinauerunt, ut unus ex illis in ciuitatem iret et expensas aportaret. Eo uero abeunte cogitauerunt, ut eum, cum in foueam descenderet, interficerent. Ipse uero uadens eciam cogitauit de perdicione istorum duorum, uenenumque comparans omnia cibaria intoxicauit ueniensque ad illos dixit: Volumusne prius comedere uel thezaurum excipere? Qui responderunt: «Prius thezaurum excipiemus». Feceruntque illum ad foueam descendere, ut eum occiderent. Descendente uero eo ipsum occiderunt et ipsi postmodum comedentes ambo mortui sunt et sic thezaurum intactum reliquerunt. Quo cum heremita (dum) uenisset et eos mortuos uidisset, ait: Vere non est aliud thezaurus nisi periculum et mors.

«Cuento de la avaricia. Un ermitaño que quería tener un jardincillo en un bosque, cavando al azar encontró un tesoro y al punto clamó tres veces con grandes voces:

-Muerte, muerte, muerte.

Tres compañeros mercaderes que pasaban por allí cerca, al oírle se acercaron y le preguntaron:

-¿Dónde está la muerte que tú estás llamando?

El ermitaño les mostró el tesoro y en cuanto lo vieron le echaron de aquel sitio: él entonces se retiró y se refugió en su celda. Mientras tanto, aquellos tres socios, pensando lo que harían, decidieron por fin que uno de ellos fuese a la ciudad para buscar todo lo necesario para sacar el tesoro. En cuanto se hubo marchado, los otros dos acordaron que cuando bajase al hoyo le matarían, pero el que se había marchado también pensó en la perdición de los otros dos y compró veneno con el que intoxicó toda la comida, después de lo cual volvió y les dijo:

-¿Queréis que comamos primero o saquemos el tesoro?

Ellos respondieron:

-Saquemos el tesoro lo primero.

Hicieron que bajase él a la fosa para cumplir su propósito y efectivamente, cuando estuvo abajo le mataron. Después se pusieron a comer y ambos murieron envenenados, con lo que dejaron intacto el tesoro. Cuando volvió el ermitaño y vio a los tres muertos, dijo:

-Verdaderamente el único tesoro que había era el peligro y la muerte ${ }^{17} \gg$.

Esta forma del relato corresponde a una tradición propia de los exempla europeos. El mismo argumento se encuentra en una Rappresentazione di Sant'Antonio (d'Ancona 1872, pp.33-63), donde queda claro el origen demoníaco del oro, del que se sirve el espíritu de la avaricia para tentar al santo ermitaño ${ }^{18}$. La misma historia se encuentra en un segundo relato del Novellino, que no aparecía en la primera edición de esta obra (LXXXII, Qui conta d'uno romito che andando per un luogo foresto trouo molto grande Tesoro) y en un exemplum de San Vicente Ferrer (Lacarra 1999, pp.241-243). Similar es también uno de los ejemplos literarios más famosos de esta

\footnotetext{
${ }^{17}$ Esta traducción es la que figura en Menéndez Pidal (1958, p.235).

${ }^{18}$ Muy parecida es la versión de Hans Sachs. Un ermitaño encuentra en un bosque un gran tesoro en un tronco y sale huyendo de él. Tres asesinos le preguntan la razón de su huída. Él responde: «He visto la muerte». Creen que los engaña y lo matan. $C f$. Hart (1911).
} 
historia, The Pardoner's Tale en los Canterbury Tales, de Chaucer. En la historia de Chaucer tres jóvenes llevan en Flandes una vida disoluta. Tienen noticia de la muerte de un compañero y en su fanfarronería, fruto de la ebriedad, se juran salir al encuentro de la Muerte. En el camino, un mendigo al que ofenden les indica un roble junto al cual podrán hallarla. Lo que encuentran es un montón de oro.

A esta misma tradición de exempla corresponde también un epigrama latino, obra del escritor del siglo XVII Giambattista Bargiocchi, compuesto en dísticos elegíacos ${ }^{19}$ :

Quam colit, in cauea foelix habitator eremi corde tremens aurum repperit, atque fugit.

Occurrunt illi noti tres nomine fures, Et «pauido nimirum quo fugis ore?» petunt.

«Heu! mortem fugio» respondet: «scilicet aurum, quod mea defossum scrupea cella tegit.»

Audito fures auri uel nomine, currunt, atque ima in fouea fulua metalla vident.

Sed cursu recubant fessi, mittuntque sodalem, Qui referens undam pellat ab ore sitim.

Ilicet hic Lympham statuit uitiare ueneno, tam diues pondus solus ut inde ferat.

At contra, aequali socii quo parte fruantur; clam misero gladiis funera saeua parant.

Iamque duo biberant, cum tertius occidit ense, et mox hausta duos atra uenena necant.

Sic tres inuento pariter moriuntur ab auro.

Qui fugit ergo aurum, non fugit ille necem?

«Un feliz eremita encuentra, embargado de miedo el corazón, oro en la cueva en la que habita y sale huyendo. Tres conocidos ladrones le salen al encuentro y le preguntan: «¿Adónde huyes con el rostro tan espantado?» «Ay! Huyo de la muerte; es decir, del oro desenterrado que mi rocosa celda oculta.» $\mathrm{Al}$ oír tan sólo la palabra oro, los ladrones salen corriendo, y en el fondo de la fosa ven el dorado metal. Pero fatigados por la carrera se tienden y envían a uno de los tres camaradas para que trayendo agua ahuyente su sed. Al punto éste decide emponzoñar el agua con veneno, para ser el único en llevarse de allí tan rica carga de oro. Pero del otro lado sus compañeros, para disfrutarlo repartiéndoselo entre ellos a partes iguales, se disponen a dar muerte cruelmente al desdichado con sus espadas. Y ya los dos habían bebido, cuando el tercero muere por la espada, y luego a los otros dos da muerte el negro veneno que habían bebido. Así los tres murieron por igual a causa del oro que habían encontrado. ¿No demuestra esto, pues, que quien huye del oro está huyendo en realidad de la muerte?»

Una versión de este tipo aparece en la obra de Francisco Santos, Gigantones en Madrid (1666, pp.142-146). Un ermitaño grita a grandes voces que lo persiguen la muerte y el demonio. Al salir de su albergue ese día ha visto un tesoro de gran valor.

19 II.102, Tres fures mortem in auro inueniunt, quam timens Eremi incola fugerat (Bargiocchi 1660, p.160). 
Tres bandoleros le obligan a enseñarles el tesoro. Siguen los planes para los asesinatos, con la novedad de que el que trae las provisiones cuenta en este caso con la complicidad de un amigo, también ladrón. Será éste, que había quedado escondido, quien cargue al final con toda la riqueza, pero sólo para caer en manos de la justicia y ser ahorcado.

A esta tradición responde también un relato de los Cento racconti raccolti da Michele Somma (Somma 1821, pp.13-15). El autor se preocupa de explicarnos la biografía del ermitaño. Se trata de un gentilhombre, que dentro de lo que podría ser la biografía ejemplar de un eremita, ha abandonado el mundo y entregado sus riquezas a los pobres.

En la tradición de los exempla el ermitaño encuentra el oro cuando está cavando un modesto jardín o cuando hace reformas en su humilde choza. El eremita del relato de Somma ha renunciado a cualquier comodidad, su morada no puede ser más humilde y carece de agua, que sólo puede conseguir yendo a buscarla a gran distancia. De camino, al sentarse en una roca para descansar, descubre el tesoro, lo que lo obliga a renovar su elección vital:

ad una tal vista tutto pieno di ammirazione il povero Romito, esclamando disse: e come ho abbandonato e ricchezze, agi, ed averi; mi son rintanato in sì orrida solitudine per non esserne vittima infelice, eppure qui mi si presentan danari? Ah maledetto danaro! Così dicendo voltò nuovamente la pietra, e proseguì nuovamente il cammino.

Unos soldados, que se entregan a actos de bandidaje, obligan al eremita a guiarlos hasta el tesoro. Los ladrones son aquí ocho, divididos en dos grupos de cuatro. El número amplifica el efecto que producen las consecuencias desastrosas del descubrimiento del dinero. Aumenta también el contraste entre la banda de ladrones y la soledad del ermitaño. El aparente compañerismo no ofrece, sin embargo, ninguna seguridad. El peligro lo llevan dentro de ellos mismos y el desierto cobra un sentido simbólico. Símbolo de renuncia a toda comodidad o placer de los sentidos por parte del ermitaño, es también el yermo espiritual en que viven los soldados. Uno de los ladrones, moribundo, da testimonio de lo sucedido, contándoselo al ermitaño. Se confirma así la opinión del eremita sobre el dinero, moralidad interna de la historia paralela a la moraleja final: Ah P. Romito, dicevate bene, che i danari, e le ricchezze son la rovina dell' uomo, e che lo mandano all' Inferno ${ }^{20}$.

En tales relatos todos los personajes cumplen una doble función, como participantes en la acción y como centros ideológicos. La personificación de la muerte en la frase del ermitaño es una variante más de las comparaciones o metáforas que en las distintas versiones de este cuento sirven para formular explícitamente el tema del

\footnotetext{
${ }^{20}$ La moraleja del narrador, en cambio, se multiplica: Da questo racconto potrà ognuno ricavare, che 1 'attacco smoderato al danaro sia sicura strada che conduce alla perdizione, e chi malamente vive, pessimamente muore; e che finalmente anche ne'deserti, senza l'ajuto della divina grazia, si corre pericolo di dannarsi.
} 
relato. Los ladrones, en cambio, desprecian, como el discípulo descarriado de otras versiones, la lección del ermitaño y en alguno de los textos afirman explícitamente que el tesoro es vida.

\section{LA LECCIÓN OSCURA Y EL RASTRO DE SANGRE}

En un relato del Libro de las tierras vírgenes de R. Kipling (1895, pp.159-190) Kaa, la serpiente, amiga de Mowgli, lo conduce hasta la guarida de una cobra, en las ruinas de una antigua ciudad, ahora destruida, en medio de la selva. La serpiente había sido encargada de vigilar el tesoro real, pero ahora su función ya no tiene sentido. La cobra trata de matar a Mowgli, pero la vejez la ha vuelto inofensiva. De los tesoros que guarda, Mowgli sólo toma el objeto que da título al cuento, el ankus del rey, un garfio para conducir elefantes, adornado con diversas piedras preciosas. La cobra repite con insistencia que lo que se lleva es la muerte. Mowgli consulta a Bagheera, la pantera, que ha tenido contacto con los hombres, y, enterado de la función del objeto, lo arroja lejos de sí. La joya da lugar a una serie de asesinatos, que concluye con una situación similar a la de los asesinatos cruzados. El joven, que ha quedado convencido finalmente de la afirmación de la serpiente devuelve el objeto a la cobra, recomendándole que busque un guardián más joven para el tesoro.

El personaje de la cobra anciana corresponde al desarrollo de los aspectos más antipáticos del eremita o del maestro espiritual de las versiones antiguas. Su lección es cierta y el protagonista acabará por comprobarla mediante la experiencia. La vieja serpiente ha permanecido durante mucho tiempo recluida en la cueva donde se encuentra el tesoro; ha cumplido su función incluso cuando ya no tiene sentido y la ciudad que existía sobre ella ha desaparecido; corresponde al ermitaño de los exempla o al vagabundo de Chaucer. Cuando Mowgli se despide de la serpiente que custodia el tesoro, ésta se dirige a él de forma que recuerda claramente las afirmaciones similares del eremita:

See, then, that the thing does not kill thee at last. It is Death! Remember, it is Death! There is enough in that thing to kill the men of all my city. Not long wilt thou hold it. Jungle Man, nor he who takes it from thee. They will kill, and kill, and kill for its sake! My strength is dried up, but the ankus will do my work. It is Death! It is Death! It is Death!

Tales frases constituyen la formulación explícita del tema de la historia. En Kipling la frase de la serpiente será debatida luego una y otra vez, hasta llegar a la completa comprensión y aceptación final de su significado por la pareja de personajes observadores que siguen las huellas de la muerte. El cuento de Kipling supone un paso más en la evolución de la historia desde el carácter doctrinalmente monolítico a la ambigüedad del relato moderno. Si comparamos el relato del autor inglés con las versiones tradicionales del cuento, queda claro que la pareja cobra-Mowgli corresponde a la de maestro-discípulo descarriado de las historias clásicas. Y como 
en éstas, es el discípulo rebelde el que provoca el inicio de la historia. Al mismo tiempo, la naturaleza ascética de la cobra, cuya vida aparece dedicada completamente a una sola misión y se desarrolla en la oscuridad, recuerda al personaje del ermitaño. Es la suya, por otra parte, una misión estéril; su ancianidad, más que aportarle la sabiduría de la experiencia, conlleva la ineficacia para cumplir su destino, y la obcecación intelectual que le impide comprender las cambiantes circunstancias de la realidad.

La propia serpiente puede considerarse como la plasmación argumental de la vieja metáfora que encontrábamos ya en los Avadânas: «el oro es una serpiente venenosa»; la historia misma puede verse como el desarrollo de la metáfora tantas veces repetida en la apertura y en el cierre del relato: el oro y la codicia son la muerte. En un proceso metafórico similar el ankus, que el joven toma en principio como un cuchillo, resulta, por una parte, no ser realmente un arma, sino, de acuerdo con su función primaria, un instrumento de la dominación del hombre sobre los animales, mientras que, por otra, en cuanto joya, resulta más letal para el hombre que cualquier arma.

En este caso el relato desarrolla ampliamente las dos funciones de los personajes en cuestión: la de observadores, con la pantera y el muchacho siguiendo el rastro de sangre, y la de los personajes como centros ideológicos del relato. Se contraponen, por otra parte, el mundo humano y el mundo natural, representado por los personajes de la selva, como Kaa, incapaces de comprender aquél, mientras que el muchacho y la pantera, que ha vivido entre los hombres, actúan como mediadores.

\section{EL TENTADOR}

En algunos casos el dinero se presenta como tentación. En el milagro de S. Antonio era de hecho una creación demoníaca para tentar al ermitaño. En otras versiones es un agente humano quien lo deja en el camino de su víctima para ponerlo a prueba. Así, en un cuento africano (Hamel - Merrill 1991) tres hombres discuten sobre la razón por la que los humanos mueren. Uno afirma que es por causa divina, el otro por causas naturales y el tercero por culpa de los malos espíritus. Incapaces de ponerse de acuerdo recurren al jefe de la aldea. Éste les contesta que no puede darles una respuesta inmediata; antes, ellos deben emprender un viaje al día siguiente. Luego encarga a su hijo que ponga una gran suma de dinero donde ellos puedan encontrarlo. La historia acaba con el relato de los asesinatos. En este caso son los propios protagonistas de los crímenes los que plantean el tema, mientras que el jefe de la aldea hace el papel de maestro, pero se niega a verbalizar la enseñanza, dejando que sean los hechos los que la pongan de manifiesto.

En un cuento popular esloveno (Maly - Hulpach 1993, pp.41-44) un hombre pobre atraviesa un bosque; se lamenta de su situación y ruega al Señor. No desea, sin embargo, dinero porque no le traería la felicidad. Sus lamentos son oídos por un ban- 
dido escondido, quien, para ponerlo a prueba, deposita en su camino una bolsa llena de dinero. El pobre deja la bolsa en su lugar. Cuatro vagabundos descubren la bolsa y se dividen, al marchar dos a buscar provisiones; los dos grupos acaban dándose muerte unos a otros, aunque sin el envenenamiento típico. El ladrón, que ha asistido escondido al desenlace, abandona su oficio y se instala en las afueras de un pueblo próximo, decidido a trabajar honestamente. El azar conduce hasta allí al pobre, que le pide trabajo, lo que le es concedido, con la condición de no darle dinero.

En este caso el agente que provoca la aparición del tesoro es él mismo un ladrón y viene a desempeñar el papel de discípulo, no de maestro. El hombre pobre que rechaza el dinero es, como puede verse, el encargado de verbalizar el tema del relato. El ladrón que lo oye escondido lo pone a prueba haciéndole encontrar el dinero. Al rechazarlo, el hombre pobre actúa como equivalente del eremita de los relatos antiguos. El ladrón contempla entonces escondido el desenlace de la historia con los asesinatos $\mathrm{y}$, finalmente, confirma la enseñanza del hombre pobre.

\section{EL ORIGEN DEL TESORO Y SUS IMPLICACIONES}

La historia del tesoro maldito ofrece distintas posibilidades a propósito del descubrimiento del oro. Curiosamente los ejemplos en que el tesoro es fruto de un robo son, contra lo que podría en principio esperarse, poco frecuentes ${ }^{21}$. Una razón probable para ello es que el mensaje en este caso sería simplemente una mera advertencia contra la codicia, mientras que los ejemplos más antiguos del tema están ligados a un mensaje mucho más radical, ascético, de renuncia al mundo y a la riqueza, ligado a la vida eremítica o monástica ${ }^{22}$.

Con frecuencia el tesoro es fruto de una intervención sobrenatural o mágica; es creado por Dios o por Cristo o cae del cielo por la recitación de una fórmula mágica ${ }^{23}$.

${ }^{21}$ En una de las versiones de las Mil y una noches (Clouston 1887, pp.390-391) dos estafadores se unen a un rico comerciante durante su viaje y deciden apoderarse de sus riquezas. Pero ambos conspiran el uno contra el otro y se dan muerte como en los otros ejemplos de esta historia. De este modo, el comerciante queda finalmente dueño de sus propias riquezas. En un relato etíope (Mengesha - Tosello 1993, pp.74-75) tres ladrones roban a un hombre rico y obtienen un gran botín, que transportan hasta un bosque. Más tarde deciden enviar a uno de ellos a por víveres y la historia sigue su cauce habitual. Tras las muertes, el botín regresa a su legítimo dueño. En un relato moralizante del XIX (Schmid 1862, pp.119-121) tres ladrones obtienen igualmente su botín mediante el robo y el asesinato. Tras el final habitual, el autor añade la siguiente moralidad: De Dieu souvent l'éternelle justice / rend le coupable auteur de son propre supplice.

22 Tampoco es habitual que la riqueza sea propiedad desde un principio de los protagonistas. Un caso en que esto ocurre es el de una leyenda veneciana transmitida por Thomas Coryat. $C f$. Kittredge (1900). Cuatro hermanos nobles provenientes de Albania llegan juntos a Venecia en un barco cargado con gran cantidad de riquezas; dos de ellos bajan a tierra, mientras los otros dos permanecen en la nave. Sigue la historia de los asesinatos. La Señoría de Venecia se apodera de todos los bienes y en recuerdo de los hermanos se erigen unas imágenes.

${ }^{23}$ En un relato de Cachemira (Knowles 1885, pp.45-46) cuatro hombres parten en busca de fortuna y encuentran un árbol cuyos frutos son de oro. Deciden entonces que dos de ellos vayan a comprar instrumentos para cortar el árbol, mientras que los otros dos se quedan guardando el preciado tesoro. Sigue luego la historia habitual de los asesinatos. 
En otras versiones no se nos explica el origen; pero su descubrimiento está ligado a la figura de Cristo o de otro personaje equivalente; o bien, inversamente, es una creación demoníaca, que sirve para tentar al hombre. En ocasiones el tesoro está inicialmente enterrado y se encuentra en el cementerio o en una tumba ${ }^{24}$. Nos hallamos, pues, esencialmente ante dos casos opuestos con respecto a su origen: o bien es un don divino que los hombres corrompen o bien está enterrado. La localización frecuente del oro en una tumba parece sugerir un ciclo que se repite; tras los asesinatos, el oro permanece en el lugar, listo para iniciar de nuevo su mortífera influencia; por contigüidad se subraya la relación entre el tesoro y la muerte. Similares asociaciones con el pasado y la muerte van unidas a su localización entre las ruinas de una ciudad. En los relatos europeos el tesoro era descubierto por un eremita al cavar; en otras ocasiones es encontrado por viajeros al borde del camino, lo que subraya su conexión con la faceta inestable y contingente de la vida.

En el relato de Morlini del que partíamos en este trabajo se combinan ambas variantes: el tesoro es descubierto, como en el relato budista, mediante fórmulas mágicas, pero está, como en otras versiones, enterrado. Quien lo descubre es un mago que lo encuentra recitando fórmulas mágicas y gracias a una revelación de los espíritus. El tesoro está, por otra parte, enterrado en una fosa o caverna.

El personaje del mago, que sólo parece servir para descubrir el oro, nos recuerda claramente al brahmán del cuento jataka que hacía que las joyas cayeran del cielo mediante la recitación de una fórmula mágica.

Desgraciadamente el estado corrupto del texto no nos permite hacernos una idea clara de la situación. Sólo a través de la comparación con los otros ejemplos del tipo podemos hacernos una idea adecuada del relato del escritor napolitano.

La narración parece implicar que el mago busca socios para su empresa, pues inmediatamente se pasa a hablar de sus compañeros sin que volvamos a saber nada del mago ¿tal vez ha sido asesinado? Esto correspondería igualmente a la historia del discípulo descarriado. Por otra parte, aquí no se trata de dos o tres ladrones, sino de un número indeterminado que van a comprar las provisiones y que son a su vez asesinados por los que se habían quedado. En las versiones occidentales, como hemos visto, suele ser bastante reducido, mientras que en el cuento jataka se habla de dos bandas de quinientos ladrones ${ }^{25}$. El relato de Morlini, por tanto, no parece depender, pues, directamente de las versiones medievales y cabe pensar en

\footnotetext{
${ }^{24}$ La tumba como lugar del tesoro se encuentra en un cuento portugués (Braga 1999, p.86). Cuatro ladrones, perseguidos por la justicia, se esconden en una cueva. Descubren un monumento fúnebre y piensan que debe ser la tumba de una persona rica. En efecto encuentran oro, plata y piedras preciosas. Discuten quién debe ir a por provisiones a la ciudad; todos se excusan afirmando ser conocidos en ella. Finalmente uno se ofrece voluntario a cambio de que le entreguen una copa especialmente hermosa. Los otros aceptan, pero por el camino envenena los alimentos, mientras que en su ausencia los otros planean asesinarlo, provocando un derrumbamiento cuando vaya a recoger la copa, con lo que al final mueren todos.

${ }^{25}$ Coincidencia con las versiones musulmanas y medievales es, por el contrario, la frase en la que señala que la codicia es la raíz de todos los males, puesta aquí, sin embargo, en boca del propio narrador y no de un personaje, y la conclusión de la narración, en la que se resalta que los muertos no son enterrados sino que quedan al aire libre.
} 
la posibilidad de una fuente popular, lo que explicaría su proximidad a las versiones orientales.

\section{DEL RELATO EDIFICANTE AL CUENTO DE FICCIÓN}

A lo largo de su evolución el relato ha ido adaptándose a distintos géneros. En la Edad Media forma parte de los exempla, mientras que en el XVIII se integra en la tradición de la fábula. También lo hemos visto como novella o facetia a la manera italiana. Pero el cambio fundamental es el paso de un relato edificante, ejemplar, a un cuento moderno, entendido como ficción.

El cuento ha estado vinculado en sus orígenes a la tradición oral sapiencial. En la literatura occidental está estrechamente asociado al exemplum y la fábula. Como relato basado en la función tropológica, el exemplum, que individualiza un episodio con una finalidad moralizante, no es propiamente ficción.

Frente al cuento literario moderno, los géneros edificantes deben presentar una moral inequívoca. En la narración cotidiana, no literaria, las historias se cuentan siempre a propósito de algo. Incluso así la narración no literaria suele incluir elementos que permiten conectar el relato mismo con el contexto de la conversación, como el anuncio del tema o la evaluación final. En las colecciones de fábulas o de exempla el anuncio del tema y la moralidad final se convierten en partes de la estructura del texto. La fábula antigua incluía, junto a la narración, el promythion, que indica a qué circunstancias se aplica la historia, y el epimythion (la «moraleja»o «moralidad»), en el que se formula la verdad general que resulta de ella, aunque uno de estos dos elementos pueda estar ausente. El promythion no es en realidad otra cosa que una variante del anuncio del tema y la formulación de la relevancia del relato; el epimithion corresponde a la «evaluación» con que se concluye habitualmente. Al quedar las fábulas aisladas contextualmente y reunidas en colecciones, tales elementos cambian de naturaleza, al adquirir la función de prevenir la aplicación del relato a la multiplicidad de situaciones posibles ${ }^{26}$.

En la tradición sapiencial es frecuente, por otra parte, que el propio relato oriente la interpretación. En el texto del Novellino la historia propiamente dicha se desarrolla en el tiempo que transcurre entre el paso de Cristo y sus discípulos y su regreso. Cristo formula el «tema» del relato y la moraleja final, lo que dentro del plano intradiegético corresponde a la enunciación del tema (el promythion, por el que se indica la relevancia de la historia) y a la moralidad o moraleja tradicional (el epimythion de las fábulas), que habitualmente encontramos a nivel extradiegético:

\footnotetext{
${ }^{26}$ He aquí la conclusión de nuestra historia en el Ci nous dit (Blanguez 1979,p.164). Los cuatro participantes de esta versión acaban muertos y el texto concluye del siguiente modo: Li.IIII. varleiz furent morz et la pierre demoura toute sainne. Si pouons entendre que les choses terriennes sont mort a ceulz qui n'en soivent bien user. Que.C. home se dampnent bien de un heritage, et adés demeure li heritages en sa plaice: c'est la pierre d'or qui ne se muet.
} 


\begin{tabular}{|l|l|l|}
\hline & Extradiegético & Intradiegético \\
\hline $\begin{array}{l}\text { Inicio: creación de } \\
\text { una expectativa }\end{array}$ & Anuncio del tema & $\begin{array}{l}\text { Verbalización explícita del tema } \\
\text { del relato en la frase enigmática } \\
\text { pronunciada por un personaje: «El oro } \\
\text { es la muerte». }\end{array}$ \\
\hline $\begin{array}{l}\text { Conclusión: «cierre» } \\
\text { del texto }\end{array}$ & Moralidad & $\begin{array}{l}\text { Agudeza final o punta, repetición de } \\
\text { la sentencia inicial o formulación de } \\
\text { una nueva: «Este dinero es el mundo; } \\
\text { he aquí lo que les sucede a quienes } \\
\text { lo siguen»; «en verdad, el oro es la } \\
\text { muerte». }\end{array}$ \\
\hline
\end{tabular}

El relato literario moderno, en cambio, debido a su propio aislamiento, impide reducir la historia a la moralidad. La significación literaria no se agota nunca en una simple moraleja. Tanto el exemplum como la fábula orientaban la interpretación del lector en una dirección determinada, mediante los mecanismos internos del propio relato. Pero, a pesar de que la poética clasicista proclamaba que la moraleja era «el alma de la fábula», en la fábula poética, ya desde Fedro y La Fontaine, la moraleja resulta con frecuencia manifiestamente insatisfactoria y los autores explotan incluso en ocasiones dicha inadecuación. El contraste entre exemplum y cuento moderno se pone, pues, de manifiesto en una mayor ambigüedad del significado. Como si en el relato moderno el género se volviera intertextualmente contra sí mismo, expresando la desconfianza en la posibilidad, implícita en las formas antiguas, de encontrar sentido y coherencia en el mundo.

A medida que el tema del tesoro maldito se literaturiza, es visible un proceso de dramatización, por el que los ladrones se convierten en centros ideológicos que hacen, en parte, las funciones que en los otros cuentos desempeñaban los personajes que actuaban como meros observadores.

Junto a la dramatización procedente de la adquisición de roles ideológicos por parte de los personajes, existe otra puramente narrativa. Las versiones más antiguas contaban la historia sin elipsis. Habitualmente el relato nos informa de los planes de un bando y más tarde del otro, para acabar con el relato de las muertes sucesivas. La elipsis parece evitada intencionadamente. Algunas versiones modernas sí que explotan, en cambio, las posibilidades en este terreno, ocultando hasta la conclusión los planes de envenenamiento del ladrón que marcha a por provisiones. De este modo los dos ladrones que se ponen de acuerdo mueren a manos de alguien que ya ha muerto y que se venga así póstumamente; el suspense aumenta al descubrirse sólo al final las intenciones de la primera víctima. Más rara es la otra posibilidad, la de que se nos descubran primero los planes de envenenamiento y se nos oculten los del otro bando, de forma que nos veamos sorprendidos por el primer asesinato. 
En las versiones del relato como exemplum existe una clara tendencia hacia la metaforización de la historia. Ya hemos tenido ocasión de comentar, por ejemplo, el juego con la personificación de la muerte en Chaucer y en la literatura ejemplar. Cuando se nos dice que el oro es la muerte se trata, en realidad, de una variante complicada de metonimia; la enigmática frase anticipa los asesinatos y se ve confirmada por ellos. Algo similar ocurre con el veneno, que adquiere valores metafóricos en otros textos.

Un ejemplo de versión literaria moderna de la historia es el famosísimo cuento de Eça de Queiroz (1964). Las diferencias argumentales con respecto al relato tradicional son mínimas. La condición de hermanos de los personajes acentúa el horror de los crímenes. El detalle novedoso de las tres llaves con que se cierra el cofre del tesoro hace inevitables los asesinatos, pues el simple robo no basta. El autor aprovecha las posibilidades de dramatización de la historia y mantiene en silencio el plan del envenenador. Rui, uno de los dos hermanos que se han quedado con el tesoro, convence al otro para que asesine al que se ha marchado, pero, con una nueva elipsis, no se nos advierte de que Rui piensa matar después a su cómplice. El estilo indirecto libre nos hace partícipes de los pensamientos del personaje al tiempo que pone de manifiesto irónicamente su hipocresía.

Una diferencia importante es que los protagonistas son hidalgos asturianos y no ladrones o viajeros. Esta caracterización de los personajes los sitúa en el tiempo histórico. Es éste un resultado aparentemente paradójico de la aceptación de la condición de ficción del relato moderno. El autor se detiene en el estado de extrema necesidad de los protagonistas, que viven en un castillo destartalado, privados de cualquier medio económico y casi de los medios para la mera subsistencia.

Podemos sospechar que los tres hidalgos encarnan en realidad el antiguo régimen, la tradición, desenmascarada precisamente con una historia no menos tradicional. La codicia y la rapacidad que los hidalgos demuestran no son sino los propios de su condición de representantes de un tiempo en que heroicidad y crimen iban unidos de la mano. La misma caracterización de los personajes (el hermano astuto, el fuerte, pero torpe e inculto y el jugador) corresponde claramente a la triada (de virtudes o de castas sociales) que encontramos con frecuencia en el pensamiento medieval.

En el cuento de Eça de Queiroz, en el cofre del tesoro hay una inscripción árabe y misteriosa (posible aviso incomprendido del destino de los codiciosos o alusión a las viejas leyendas que en toda la península hablan de tesoros escondidos en tiempos de los musulmanes). Significativamente dicha inscripción, que podría esconder el mensaje del relato, resulta ilegible. El lector no llega a conocer su significado. Del mismo modo, la vieja historia se ha vuelto polisémica.

\section{REFERENCIAS BIBLIOGRÁFICAS}

Aarne, A. - Thompson, S. (1973), The Types of the Folktale. A Classification and Bibliography, Helsinki, F.F. Communications.

Asín Palacios, M. (1919), Logia et agrapha, en Patrologia Orientalis, 13, Paris, Firmin-Didot. 
BArgiocchi, G. (1660), Io. Baptistae Bargiocchi S.J. Epigrammata sacra, moralia, demonstrativa, Romae, I. de Lazaris.

Basset, R. (1883), Contes populaires d'Afrique, Paris. E. Guilmoto.

BASSET, R. (1887), Contes populaires berbères, Paris, E. Leroux.

BASSET, R. (1927), Mille et une contes, récits et légendes arabes, III (Légendes religieuses), Paris, Librairie Orientale et Américaine, Maisonneuve.

Battaglia Ricci, L. (1982), Novelle italiane. Il Duecento. Il trecento. Introduzione, scelta dei testi, note e commenti di Lucia Battaglia Ricci, Milano, Garzanti Editore.

Blanguez, G. (1979), Ci nous dit. Recueil d'exemples moraux, publié par G. Blanguez, I, Paris, Société des Anciens Textes Français, A. et J. Picard et Cie.

Braga, T. (1999), Contos tradicionais do Povo Português, II, Lisboa, Publicaões Dom Quixote. Bret, A. (1772), Fables orientales et poésies diverses, Paris, Imprimerie Ducale.

BURTON, R. F. (1897), The book of the thousand nights and a night (Supplemental nights), IX, London, H.S. Nichols.

Canby, H.S. (1905), «Some Comments on the Sources of Chaucer's Pardoner's Tale», Modern Philology, 11, pp.477-448.

Clouston, W.A. (1887), Popular Tales and Fictions, II, Edinburgh and London, W. Blackwood.

Correale, R.M. - Hamel, M. (2003), Sources and Analogues of the Canterbury Tales, I, Cambridge, D.S. Brewer.

Cowell, E. B. (1973), The Jātaka: or stories of the Buddha's former births, I, Cambridge, University Press.

D’Ancona, A. (1872), Sacre rappresentazioni dei secoli XIV, XV e XVI, Firenze, Successori Le Monnier.

Diderot, D. (1788), Oeuvres, VII, Paris, Desray - Deterville.

EÇA DE QueIroz, J.M. (1964), «El tesoro», en Obras completas, II, Madrid, Aguilar, pp.954-964.

FABricius, J.A. (1719), Codicis Apocryphi Novi Testamenti pars tertia, Hamburgi, Schiller - Kisner.

Fradejas Lebrero, J. (1987), «El tesoro fatal», Homenaje a Álvaro Galmés de Fuentes, Madrid, Universidad de Oviedo - Gredos, 3, pp.471-483.

GALland, A. (1694), Les paroles remarquables: les bons mots et les maximes des Orientaux, La Haye, L. - H. Van Dole.

GAllud JARDIEL, E. (2000), Las hierbas de la sabiduría, Madrid, Alderabán.

Gil Grimau, R. - IBN Azzuz, M. (1988), Que por la rosa roja corrió mi sangre. Estudio y antología de la literatura oral en Marruecos, Madrid, Ediciones de la Torre.

GonzÁlez Palencia, A. (1946), «Cuentos populares marroquíes», Revista de Dialectología y Tradiciones Populares, 2, pp.331-371.

Guillén Robles, F. (1994), Leyendas moriscas, II, Madrid, Editorial Sufí.

Guiraudon, T.G. DE (1894), Bolle Fulbe: manuel de la langue foule, parlée dans la Sénégambie et le Soudan, Paris - Leipzig, H. Welter.

Hamel, M. - Merrill, CH. (1991), «The Analogues of the Pardoner's Tale and a New African Version», The Chaucer Review, 26, pp.175-183.

Hart, W.M. (1911), «The Pardoner's Tale and Der Dot im Stock», Modern philology, 4, vol. 9, pp.17-22. 
JONES, J. (1798), A new and full method of settling the canonical authority of the New Testament, I, Oxford, Clarendon Press.

Julien, S. (1859), Les Avadânas. Contes et apologues indiens inconnus jusqu'a ce jour suivis de fables et de poésies chinoises, traduction de Stanislas Julien, Paris, B. Duprat.

KhawAm, R.R. (1976), Le Livre des Ruses: la stratégie politique des Arabes, traduction intégrale sur les manuscrits originaux par René R. Khawam, Paris, Phébus.

KIPLING, R. (1895), The Second Jungle Book, New York, The Century Co.

Kittredge, G. L. (1900), «Coryat and the Pardoner's Tale», Modern Language Notes, 15, 193-194.

KLAPPER, J. (1911), Exempla aus Handschriften des Mittelalters herausgegeben von Joseph Klapper, Heidelberg, C. Winter.

KNOWLES, J.H. (1885), A dictionary of Kashmiri proverbs \& sayings, explained and illustrated from the rich and interesting folklore of the valley, Bombay, Education Society's Press.

LACARra, M.J. (1999), Cuento y novela corta en España I. Edad Media, Barcelona, Crítica.

Maly, M. y Hulpach, V. (1993), Contes des Balkans, F. y K. Tabery (eds.), París, Gründ.

MARZOLPH, U. (2004), «Schatzfinder morden einander», Enzyclopädie des Märchens XI, Berlin - New York, Walter de Gruyter, pp.1282-1290.

Mayeur de St. Paul, F.M. (1786), Étrennes du Parnasse: Choix de poésies, Paris, Belin - Brunet.

MeIdinger, J.V. (1792), Traits d'histoires fort amusans, Frackfort, André.

Morlini, G. (1983), Novelle e favole. A cura di Giovanni Villani, Roma, Salerno Editrice.

MenÉndez Pidal, R. (1958), Antología de cuentos de la Literatura Universal. Estudio preliminar de R. Menéndez Pidal, Barcelona, Labor.

Mengesha, Sh. - Tosello, M. (1993), Fiabe Etiopi, Milano, Mondadori.

Neufchâteau, N.F. De (1815), Poésies II, Fables et contes en vers, Paris, P. Didot l'aîné.

Pedrosa, J.M. (2000), «Más reescrituras del cuento de El tesoro fatal (AT 763): Del Orto do esposo, Vicente Ferrer y Hans Sachs a Eza de Queiroz, William Faulkner y Max Aub», Revista de poética medieval, 5, 27-43.

PICK, B. (1908), Paralipomena. Remains of Gospels and Sayings of Christ, Chicago, Open Court Publishing.

SAinT-Lambert, J.-F. DE (1796), Les saisons: poème, Paris, P. Didot l'aîné.

SAntos, F. (1666), Gigantones en Madrid por defuera, Madrid, Pablo del Val.

Schiefner, A. von (1988), Tibetan Tales Derived from Indian Sources, translated from the Tibetan of the Kahgyur [also spelled Kanjur] by F. Anton von Schiefner and from the German into English by W. R. S. Ralston, Delhi, [London, 1926], Sri Satguru Publications.

Schmid, CH. (1862), Les petits contes pour les enfants, Paris - Strasbourg, Veuve BergerLevrault et fils.

SidDi LeBbe, M.C. (1884), «An account of the Virgin Mary and Jesus as given by Arabic writers», The Orientalist, vol. I, part II, pp.45-47.

Somma, M. (1821), Cento racconti raccolti da Michele Somma dell città di Nola per divertire gli amici nelle ore oziose, Napoli, A. Coda.

Thompson, S. (1955-1958), Motif-Index of Folk Literature, Bloomington, Indiana University Press.

WARner, L. (1644), Proverbiorum et sententiarum Persicarum centuria, Lugduni Batavorum, I. Maire. 